ISSN 2227-7102

www.mdpi.com/journal/education

Article

\title{
What about Global History? Dilemmas in the Selection of Content in the School Subject History
}

\author{
Jens Aage Poulsen \\ Department for Teacher Education, University College Lillebælt, Vejlevej 2, Jelling 7300, Denmark; \\ E-Mail: jeap@ucl.dk; Tel.: +45-7587-2564
}

Received: 20 July 2013; in revised form: 9 September 2013 / Accepted: 16 October 2013 /

Published: 15 November 2013

\begin{abstract}
It is a cliché, but also a fundamental fact that we live in a world where globalization and international challenges, opportunities and relationships play an increasing role. However, how have these changing conditions affected the content of school history? To what degree have curricula and textbooks addressed these challenges? Is the main focus in school history still on the history of the nation state, or has it successfully integrated topics and themes from world history? These are questions I discuss in this paper. In the main, my starting point is the situation in Denmark, but with perspectives and comparisons from Norway, England and Germany. Among other things, I will put school history in a historical context, because the subject's history and genesis - in my opinion - tends to maintain a traditional content and form of organization, thereby reducing the subject's usefulness. At the end of the paper, I outline and discuss a few alternative options for selecting and organizing the content with the aim of being more inclusive with regard to global and international aspects. The paper must be understood as a step towards the clarification of a development project that aims to propose and experiment with practices for the selection and organization of the content of the history curriculum, with the aim of increasing the international and global dimensions in history teaching.
\end{abstract}

Keywords: school history; teaching history; national vs. global history; didactic of history 


\section{History: A Controversial Subject}

Quantitatively, history is taught in a modest number of lessons in most European countries, while in some countries history is not taught separately but is integrated as an interdisciplinary subject. Just a few examples: in Denmark, history is compulsory from third to ninth grade, one or two lessons a week [1]. In Norway, history is not taught as a separate subject but as a part of social science, which also contains the subjects geography and sociology, and is taught from first to ninth grade [2]. In the German federal state of Thuringia, history is a separate subject from the sixth grade [3]. Despite its size, there has always been - at least in Denmark - considerable political attention to the subject compared with other subjects with a larger quantitative volume, such as Danish (mother tongue teaching) and mathematics.

The political decision-makers in most European countries are eager to make teaching in most school subjects as effective as possible due to global competition. It seems that history is an exception to the rule. Instead of allowing growing internalization to be reflected in the content of history, the decision-makers tend to place their nation's historical narrative at the center of their curricula; some even expect the subject to focus on preservation and to pass on an (unchanged) national heritage. Some years ago, a political majority in the Danish parliament demanded that the following sentence should be included in the first paragraph of the tripartite objective for the subject: "(history) teaching shall make the students familiar with Danish culture and history" [4]. This requirement has a significant place in the curriculum, but without an explanation of what "Danish culture and history" means in this connection. Culture can be defined in many ways: it can be defined as descriptive and static or complex and dynamic.

If the concept of culture can be characterized as descriptive and static, culture is seen as a sort of collection of ideas, values, rules and norms which people carry over from the previous generation, and which — school and other "cultural carriers" attempt to convey—perhaps slightly changed — to the next generation. Culture is a defined unit existing within the borders of the nation state. On the whole, all the people in a culture demarcated by a nation state share values, norms and rules - or at least they ought to. The subject of history is perceived in a similar way - at least the teaching of history. The subject's main task is to convey knowledge about the core history—or the cultural heritage — of the nation state to the next generation.

If the concept of culture can be characterized as complex and dynamic, culture is seen as something we do, i.e., knowledge, meaning and values that people negotiate and share with others in various social communities. Therefore, culture is always in development and change and so in this connection is a social-constructivist concept of history.

Although many people in Denmark-from decision-makers to parents and even some history teachers - support the first-mentioned concept of history and culture, the curriculum can also contain the second concept. In my opinion this concept is more appropriate in a globalized world.

In this paper, I discuss history as a school subject and its usefulness in a world where globalization and international challenges, opportunities and relationships play an increasing role. At the end of the paper, I outline and discuss some alternative options for selecting and organizing the content with the aim of being more inclusive with regard to global and international aspects. 


\section{The Task of the School Subject}

The range of school subjects is not identical from country to country; and the tasks they perform and the reasons why they are on the school schedule are often different. However, one thing is for sure: school subjects are not important in themselves. Students are not taught history in order to educate them to be professional historians. The subjects are tools or means to acquire knowledge, skills and attitudes, which are only important if they can help to meet the overall aim of the school. All European countries have compulsory school attendance for nine years or more. Each country has its unique overall aims for schooling. Nevertheless, seen from an overarching perspective, three common aims can be identified: (1) to enhance the students' personal and all-round development or general education (German: Bildung); (2) to ensure that students become useful members of society, that is, the way in which they have to acquire knowledge, skills and attitudes preparing them for further studies and working life; (3) to construct a feeling of responsibility, solidarity and belonging to the society (nation state) and to fellow citizens.

How can the subject history be legitimized in this context? Generally, the teacher must endeavor to organize teaching that enables the students to acquire knowledge and skills to orient them in time "backward", "forward" and "contemporary", i.e., strengthen the students' historical consciousness. This implies that teaching is organized for the students to practice and advance their capacity to analyze, interpret and construct meaningful and valid explanations of why our age has turned out the way it is. This means that the students must acquire knowledge of historical processes of continuity and change - including the ability to judge the nature and extent of change. This knowledge is a prerequisite to understanding, relating to their time and life and to size up their opportunities in the future. Of course, this main objective is formulated in different ways in the aims or goals for teaching history in each country, but on the whole, the objectives are similar. Here are just three examples to support the statement:

In the German federal state of Thüringen the purpose of teaching the subject is initially formulated in this way (author's translation from German into English):

"The central goal of teaching the subject history is the training and development of independent historical thinking. The independent and reflective engagement with history provides a basis for the orientation of the students in their current world and allows them the responsible use of the wide range of interpretation and identification of available historical culture" [5].

In Denmark (author's translation from Danish into English):

"(Teaching is supposed to strengthen) the understanding of historical contexts and give them (the students) practice in using this understanding in their everyday life and society" [4].

In Norway (author's translation from Norwegian into English):

"(History) focuses on examining and discussing how people and society have changed over the centuries. History also includes how humans create and shape their own understanding 
of the past. Developing historical overviews and insight, and training skills in everyday life and participation in society are key elements of this subject area" [2].

The task of the history teaching, in order to promote students to become useful citizens is also about political education (Bildung) — including promoting students' understanding of social solidarity and coherence. These are core elements in what is called citizenship education. In some countries, citizenship education is taught as a separate subject, while in others it is integrated with other subjects. In Norway, the objectives of the subject social studies begin as follows (author's translation from Norwegian into English):

"The purpose of social studies is to help create understanding and belief in fundamental human rights, democratic values and equality, and to encourage the idea of active citizenship and democratic participation" [2].

It appears that the quotes regarding the purpose of teaching history are similar, and perhaps they could be accepted in almost all countries in the world, or even be accepted as a universal purpose of teaching history. However, when you move towards a more concrete level — the curricula and teaching materials - there will be differences.

\section{Curricula and Textbooks}

For better or worse, we live in increasingly global conditions: politically, economically, socially and culturally. Therefore, becoming a useful citizen is not only directed towards the society that is defined by nation states, but must increasingly include global dimensions. In other words, teaching the subject history must also help students to understand themselves as citizens of the world and make them aware of global solidarity and responsibilities. To what extent is this the case? To what extent and in what manner are topics of world history integrated into teaching? Or is the nation state still used as the dominant criteria for the selection and organization of the teaching content? The last question about the role of the nation state is understood in two senses: The historical content is first of all the national history, for instance the history of Denmark, and the content is organized in the histories of nation states, i.e., politico-geographical areas. Within the framework of this article, it is not possible to answer the questions for all the European countries. However, I will broadly examine the question concerning the selection of content and principles for organizing the content of the history curriculum and textbooks from Denmark, England, the German city of Berlin and Norway, at least in order to point out some trends. To make some comparisons, I will focus on lower secondary history, i.e., around 7th-10th grade. Of course, it is not possible to deduce from the textbook what actually goes on in classrooms: does the textbook control the teaching, or does the teacher reflectively use the textbook as a tool? The role of textbooks and other teaching material for selecting the content and organization of teaching is a suitable topic for deeper research.

\subsection{Denmark}

The history curriculum in Denmark is called "Fælles Mål 2009” (Common Aims 2009). From the tripartite purpose of the subject mentioned previously you can deduce a general and rather open framework for choosing the content: "[...] teaching shall make the students familiar with Danish 
culture and history". History is a compulsory for all students from grades 3-9. The seven years of teaching is divided into three phases: grades 3-4, 4-6 and 7-9, each with a set of open and broadly formulated goals. Each set of goals is introduced with the sentence: "teaching should lead to the students acquiring knowledge and skills that enable them to [...]". For instance, a goal after the ninth grade is to "compare contemporary living in Denmark with other countries and discuss the historical reasons for the differences" [6]. The teachers must interpret the goals, and on this basis choose the content and organize the teaching. In addition, the goal above is the only one out of ten that mentions Denmark. Therefore, with regard to the curriculum, it is possible for the teacher to choose topics, events and themes outside of Danish history. However, there is a canonized list of 29 events and persons the teachers are obliged to integrate in the topics and themes, and the curriculum divides the 29 events and persons into the three phases and prescribes that they are taught in chronological order. Thus, this list has great influence on the content. In addition, 20 of the 29 events and persons are closely connected to the history of Denmark and the rest are from the history of Europe, while none of them are from non-European history. The consequence of this is that majority of the content in the teaching materials is Danish history sometimes connected to or with a perspective from European history - often in chronological order.

In Denmark, an example of a widely used textbook is Thomas Meloni's: Indblik og udsyn. Historie for 9. klasse, nyeste tid 1918-2010, 2010 (Insights and outlook. History for ninth grade, recent times 1918-2010) [7]. The content of the book is divided into four broad periods: "Between the wars", "The Second World War", "The Cold War" and "After the Wall", altogether consisting of 28 chapters. Some chapters focus on Danish history, and others on European history. No chapters are about non-European or non-Western history.

\subsection{England}

The content in the new British history curriculum for Key Stage 3 is divided into two sections: "British history" and "European and world history", and the curriculum prescribes:

"[...] history should be taught through a combination of overview, thematic and depth studies [...] to give pupils a secure chronological framework, the choice of content should ensure that all pupils can identify and understand the major events, changes and developments in British, European and world history covering at least the medieval, early modern, industrial and twentieth century periods" [8].

However, when you look at the list of contents, the two areas are not equal; the history of Britain is covered with in five points, with only two for European and world history. However, it seems that non-British history receives a little more coverage compared with former curricula.

A slightly older but still widely used textbook is Colin Shephard, Andy Reid, Keith Shepard: Discovering The Past Y9, Peace \& War, 1996 [9]. Although the book is written in accordance with the concept of the Schools History Project, where students work in a problem-oriented way with pedagogically prepared (linguistically simplified) extracts of sources, the topics of the textbook suit the draft of the new curriculum. The focus is strictly on British history - or at least history with a close connection to the empire, for instance a topic about the abolition of slavery. 


\subsection{Berlin-Germany}

The Berlin History Curriculum is based on competence, i.e., the standards of the students' knowledge and skills at the end of a period of teaching - here grades 7 and 8 . The competences are put into three categories: "Interpretation and analysis" (Deutungs-und Analysekompetenz), "Methods" (Metodenkompetenz) and "Judgment and orientation" (Urteils-und Orientierungskompetenz) [10], and because the school system is split into levels (Hauptschule, Realschule, Gymnasium and the mixed Gesamtschule) the competences are divided into three levels. The competences focus on skills and general knowledge and not on a specific historical content, which is shown in a separate list-in chronological order from the middle ages to industrialization. The list contains only topics and themes from European history, but not specifically German ones.

A widely used textbook is Asmut Brückmann et al:: Geschichte Geschehen-Sekundarstufe I band 2, 2009 [11]. The book consists of 10 chapters organized in themes and topics beginning with the late Roman Empire when Christianity became a state religion and ending with the religious conflicts and the Thirty Years' War. Overall, the book is completely in line with the expectations of the curriculum. The content is mainly about the history of Western Europe with some emphasis on the German area. One chapter is about the theme of the meeting or clash of cultures with the focus on the crusades, and another tells about European expansion and the conquest of colonies. In both chapters, the history is mainly seen from a European perspective, and the history of the German nation state is played down.

\subsection{Norway}

The Norwegian History Curriculum is set out as three sets of competence aims, one for each of the year groups: grades 1-4, 5-7 and 8-10. The historical content is chosen and organized chronologically, from the oldest times in the youngest classes to contemporary history in the oldest classes. In the first year group (grades 1-4), family and local history is mentioned in the competence aims, but the dominant focus is on Norwegian history from the Stone Age to the Iron Age. In the second year group the main thread from the Viking Age to the Enlightenment is also Norwegian history, but the history of national minorities living in Norway - besides the Sami people - should also be taught: "elaborate on which national minorities exist in Norway, and describe the main characteristics of the history and living conditions of these minorities", setting the scene for putting into perspective aspects from European history. In addition, the third year group (grades 8-10) has the history of Norway as the main thread. For instance: "[...] events that helped shape modern Norway [...]," "[...] important features of developments in Norwegian history in the 1800s and the first half of the 1900s", and "explain the emergence of the welfare state and describe the characteristics of modern Norway", but the student will also learn about the American and French revolutions, imperialism, de-colonization and the "central international conflicts in the 1900s" [12].

How is the curriculum reflected in a widely used textbook such as Harald Skjønsberg's: Historie 8. Samfunnsfag for ungdomssteget, 2006 (Social studies for the youth) [13]? The book covers the period from 1750 to 1814 and consists of 17 chapters, organized in three parts: "Krigar og revolusjonar" (Wars and revolutions), "Industrien endrar livet til menneska" (Industry changes the life of man) and "Da Europa rådde i verden" (When Europe ruled the world). At first the textbook is in line with the 
curriculum, although - compared with the competence aims - the book contains more non-Norwegian content than you might expect. The general principle for organizing the content is the nation states, i.e., political-geographical areas, but a few chapters go beyond this principle and have a more thematic approach, for instance a chapter named "Rebellion and repression". The content is dominated by Norwegian and European history. The few chapters on non-European issues and events, such as "Imperialism", are seen from a European perspective.

\subsection{Comparison and Summary}

I have tried to divide the content of the textbooks into four categories: (1) National history with the main focus on political, social, economic and cultural events and connections within the nation state where the textbook is used; (2) European (Western) content is understood as general topics from the history of Europe or North America or events from "another" country e.g., the French Revolution; (3) Non-European (non-Western) content is when the main focus is on general topics or events outside Europe and North America, such as the Mayas before the arrival of Spanish conquistadores; (4) Global (thematic) is trans-boundary, general historical phenomena and developments and cultural exchanges or what the American historian William H. McNeill calls ecumenical history [14].

Figure 1. Percentage coverage of National, European (Western), Non-European (Western) and global (thematic) history in textbooks.

\begin{tabular}{|l|l|l|l|l|}
\hline & National & European(Westem) & $\begin{array}{l}\text { Non-European } \\
\text { (non-Westem) }\end{array}$ & Global (thematic) \\
\hline $\begin{array}{l}\text { Denmark: } \\
\text { Thomas Meloni: } \\
\text { Indblik og udsyn, } \\
\text { Historie for 9. klasse, } \\
2010\end{array}$ & 39 & 61 & 0 & 0 \\
\hline $\begin{array}{l}\text { Colin Shepard et.al.: } \\
\text { Discovering the Past } \\
\text { Y9, Peace \& War, } \\
\text { 1996 }\end{array}$ & 74 & & & \\
\hline $\begin{array}{l}\text { Germany/Berlin: } \\
\text { Asmut Brückmann: } \\
\text { Geschichte } \\
\text { Geschehen, } \\
\text { Sekundarstufe 1, } \\
\text { band 2,2009 }\end{array}$ & 19 & 22 & 4 & 0 \\
\hline $\begin{array}{l}\text { Norwegian: } \\
\text { Harald Skjønsberg: } \\
\text { Historie 8, 2006 }\end{array}$ & & 74 & 7 & 0 \\
\hline
\end{tabular}

Although the content in some cases is mixed in relation to the chosen categories, a few tendencies can be deduced from the survey. Firstly, the British textbook is strongly focused on the national history or at least what could be called the British area. Secondly, the Danish and the Norwegian textbooks on the whole have the same division between national and European (Western) content. However, in both cases - and like the British textbook-political history dominates, and the nation state is the framework for the content. I will return to this in the next section. This differs from the approach in the German textbook, which is more generally European, for example as shown in the chapter title "Wer herrscht in Europa?" (Who rules in Europe?). No doubt the period of Nazism and Holocaust explains the downplaying of the national history of Germany in the curriculum and learning materials. It is a 
common understanding among German history teachers that their most important task is "to tell the young Germans about Nazism and Holocaust and to foster a feeling of continual responsibility of German society resulting from this period of German history" [15]. As appears from the table, non-European (Western) history is not handled, or only handled to a limited extent, by any of the textbooks. I will return to a discussion concerning the lack of non-European or world history in the curricula and textbooks. First, I will discuss the dominance of the nation state as a framework or vantage point for the content of history teaching.

\section{The Nation State as Framework for School History}

The nation state has not always been the main category in historiography. In the Middle Ages, the vantage point could be characterized as a Christian universal history organized "in the centuries following the appearance of Christ" [16]. In the Renaissance, history became a part of the education of boys in noble families, because history was seen as a means of forming the young nobleman's acquisition of virtues like self-monitoring, courage and willpower [17]. In other words, what the famous German educational researcher Wolfgang Klafki in his model of categorical formation calls classical education. In addition, when history became a subject in the Danish grammar school in the early 1700s the main focus was on the history of Antiquity.

The genesis of the modern understanding of history-both as a school subject and a scientific discipline - developed during the 19th century. History was constituted as a scientific discipline in a period when the absolute monarchies were replaced by a form of liberal democratic government, the nation became the dominant community, and one's national identity was significant in one's self-perception and perception of others. The nation states "[...] created a new historical arabesque in which the pattern of history was written from the vantage point of national histories" [18]. The 19th century was also the time of Imperialism where the idea of the civilized European/Western and the primitive and backwards non-European/Western societies and cultures emerged. The American historian William Swinton expressed the general view of that time in this way:

"Viewing history as confined to the series of leading civilized nations, we observe that it has to do with but one grand division of the human family, namely, with the Caucasian, or white race. [...] Thus we see that history concerns itself with but one highly developed type of mankind; for though the great bulk of the population of the globe has, during the whole recorded period, belonged, and does still belong, to other types of mankind, yet the Caucasians form the only truly historical race" [19].

These changing ideals and conceptions of the good society and the right way of life became the frame of historiography. It was natural for historians to use the nation state as the main principle for the framing and structuring of historical content, even if the nation state did not exist at the time. An example is the archaeologist Jørgen Jensen's set of books "Prehistoric Denmark", published at the beginning of this millennium.

As a school subject, history was a child of the nation state. In most countries, it was the main task of history teaching to legitimize and promote loyalty, identity and belonging to the state, territory and the people (the nation). Therefore the content of the teaching focused on state power, society and the 
history of the nation - often with an emphasis on stories about the national past that more or less idyllically emphasized the importance of the national community for the state, society and nation - especially when external threats occurred.

Due to historical circumstances. the nation-building processes in Denmark during the 1800 s seem to be very strong compared to other European countries. In the 1700s the Danish absolute kingdom was multicultural and multilingual. However, after the surrender of Norway in 1814 and especially after the defeat in the war with Prussia and Austria and the loss of the Duchies of Sleswig and Holstein in 1864, Denmark became a small country with only a Danish speaking population. Both from above (the government) and from below (the people) intensive nation-building was launched to protect and preserve Denmark and what was called Danishness.

Like in other countries, the school subject history played an important role in developing the students' national feelings and love for the homeland. In 1900 the curriculum-so-called Circular of Sthyr - made history a school curriculum subject. It emerges clearly from the curriculum that the time was characterized by nation-building and the perception of national community and collective identity ranked above all other communities and identities such as class, wealth, gender and occupation. The Circular clearly expressed this intention: "[...] to develop a healthy and strong imagination in connection with a warm and vivid feeling especially for our people and country [...]. With its abundance of examples addressed to the moral appreciation of the children" [20].

Historical narratives were a means to mold children's characters and personalities - including construction of a strong and jingoistic nationalism. Teaching and learning materials from that time set the scene using a collective "we" identifying all Danes-irrespective of their social and economic status and other differences. For instance, students learned that the first Danes were reindeer hunters. That is to say that from the very beginning Denmark was a national governmental entity. And since then, (usually) good and wise kings led the country and the people safely through bad times, and made progress and better conditions for all. Textbooks expressed the socialized and national task of the subject. For instance, the preamble to Nikoline Helm's De Danske og deres Broderfolk (The Danes and their sister nations), which first appeared in 1916, subsequently went through more than 20 print runs and was still in use until the late 1950s, says (author's translation from Danish to English):

"Boys and girls! Denmark is our country, which we love! It is a beautiful country with salt, sea, and a refreshing wind, and our live-in spite of the problems many have to fight against - live under more fortunate circumstances than almost all the people in the world. Is that why we are so fond of our country? No, if anything, probably because this is our home. Here our fathers and mothers were raised and their parents before them. And we know that our people lived here from ancient times." [21]

The subject content was mostly the history of Denmark, but it appears from the title of the above-mentioned textbook that students could also read a little about "the sister nations", i.e., Norway and Sweden. Other states such as Germany and Great Britain were for the most part only mentioned when "we" and "them - the other" were at war.

In the 1920s and 1930s, the curriculum of Sthyr was criticized for promoting nationalism and reinforcing enemy images. However, not before 1960 did this lead to fundamental changes in the curricula. In addition, the 1960 curriculum was something new. Compared with the previous curricula 
it was striking how much the purpose of the subject history in the new curriculum focused on the international. In the declaration of objectives, the international actually makes up more than half of the text. This can be seen as a consequence of the fact that after WWII Denmark became more politically and economically involved in the world, for instance with its membership of the United Nations in 1945, OEEC in 1948 and NATO in 1949. The greater emphasis on international content in the subject is justified by the importance of intercultural understanding assigned at the time: "[...] to consider the problems (in the world) from the standpoint of equality between peoples" and "[...] to solve mankind's common problems in a spirit of friendly international cooperation" [22]. With this emphasis on the "people's" and "mankind's common problems", you could expect a more world-history like approach and the use of categories other than the nation state in history teaching. However, that is not the case. According to the brief indication of the content of the curriculum, students should be presented with a chronological review of history with an emphasis on the history of Denmark-however, with the inclusion of certain aspects of contemporary events from world history. The historical content was organized by grade level. Thus students in third grade have to learn about in antiquity: "Denmark in the Stone Age, Bronze Age and Iron Age [...] (and) selected topics of the ancient Mediterranean cultures". In the seventh grade (where compulsory education stopped), students were taught "Denmark from 1914 to the present day with perspectives of the two world wars, the Soviet Union, Western Europe, USA, Nazism, the rise of the colonial countries, the work of the UN." So the main task of the subject history in Danish schools was to pass on the historical and cultural heritage of the nation state to the next generation.

In addition, the curricula that followed used the nation state as the dominant principle for the organization of the content - and the history of Denmark occupied most of the teaching. Therefore, the 1995, 2002 and 2004 curricula stated that:

"Danish history must be central to teaching. Students are taught about social issues, historical processes of changing and events connected to:

- the History of Denmark, including local history

- the History of Denmark in the context of the history of Scandinavia, Europe and world history

- $\quad$ the History of Europe and the World

- the History of Denmark as seen from the perspective of other cultures" [23].

As can be seen, the curriculum opens up the teaching of topics from the history of Europe and the world. Downplaying the history of the nation states to a certain extent seems to be a general tendency in several European countries in the 1990s, even in England where the National Curriculum from 1991 "[...] mandated a balance between British, European and World history" [24]. It can be seen as consequences of the fall of the Berlin Wall, the imagination of the so-called "new world order" as president Bush proclaimed in a speech in 1990.

In the new millennium - especially after 9-11-2001-you can notice a sort of reaction and a return to a more national focus in teaching history. To take Denmark as an example, in 2005 the Danish Government declared a "war for values", reasoning that what was referred to as the specific and fundamental Danish values and culture were threatened because of cultural globalization and multiculturalism. Several initiatives were put in place to prevent this development, including one 
concerning the school subject of history. In 2006, the Minister of Education appointed a so-called expert committee: the "Committee for strengthening history in Schools". Among other things it emerged from the terms of reference that the committee was expected to formulate some suggestions responding to the demands of the Government that (author's translation from Danish to English):

"History teaching should provide students with a chronological overview of events, developments and changes, which belongs to the common Danish cultural basis. [...] The Government does not believe students are sufficiently familiar with the history of Denmark nor have sufficient knowledge of the history of other nations [...]" [25].

As is apparent from the quotation, the Government's intention was to strengthen the teaching of the history of Denmark, at least the parts or elements of history which are perceived as a common cultural basis or national heritage. In addition, it is obvious, that the history of other nations is less important than the history of Denmark. Please note the form of the phrases: "the common Danish cultural basis" and "the history of Denmark". Moreover, note also that the nation state - both in Denmark's history and other nation's history - is seen as an obvious category for organizing the content of the subject. For the Government the cited "problem" was expected to be solved by introducing the previously mentioned "canon for the subject history", i.e., by canonizing "25-40 significant events in the history of Denmark and other nations".

As mentioned, the effort to re-vitalize the history and culture of the nation state can be seen in the history curriculum and guides for teaching in several European countries, for instance in England:

"[...] the idea of teaching 'British values' is now enshrined in the regulations for initial teacher education, with the stipulation that teachers must not undermine 'fundamental British values, including, democracy, the rule of law, individual liberty and mutual respect, and tolerance of those with different faiths and beliefs" [24].

\section{What is the Problem?}

As shown in this paper, the nation state has functioned as a main setting for history teaching for many years, and in many countries there is a general tendency towards placing their own historical narrative at the center of the content, so what is the problem? Why not continue to focus on the history of Denmark in school history in Denmark? Besides the fact that we live in a globalized world, there are several reasons for changing the concept. I will mention some of them. Firstly, the term "Denmark" is far from unambiguous. If you accept the national narrative - or rather the myth - that the Danish kingdom was established during the reign of Harald Bluetooth, it is first from the late 10th century that you can talk about Denmark as a geographical and political entity. Secondly, the borders of the Danish kingdom changed many times over the years-just like the borders of other countries. Thirdly, it is hardly more than 200 years ago that the population as a whole began to experience themselves as belonging to the same community (the nation). Fourthly, the country's inhabitants never lived in isolation and have not developed a specific unequivocal Danish culture and identity. Since the Bronze Age, there have been contacts - peaceful and non-peaceful — with the outside world. What is termed as Danish culture is a result of cultural encounters and cultural clashes over thousands of years. a cultural exchange that still happens, nowadays even more intensely than before. 
The nation states are not dead, as some proclaimed, predicted - or perhaps hoped for-15-25 years ago. However, it is obvious that the nation states no longer constitute a political, economic, cultural and social unity as they did previously. For better or worse, more and more in these areas happen across, and often independent of, the nation states. Since the 1980s, the concept of globalization describes these processes. People who have influence on schools, i.e., the Minister of Education, legislators and other decision makers, history teaching researchers, publishers and authors of learning materials, and not least history teachers, must reflect on the impact of globalization on content selection and the organization of teaching. If the curriculum, learning materials and teachers only choose the content from the history of the nation state, and only aim at students acquiring national historical stories and what is perceived as a national and static culture and heritage, the subject will lose its usefulness and thus the justification for its existence in schools. The consequence will be that the teaching of history will be deleted from the timetable, as happened to the subject Latin a few decades ago.

\section{Selection of Content: Alternatives}

There is too much historical content to choose from. This is an insoluble and growing problem in the teaching of history. In addition, if the content should not only be selected from the history of the nation state but also from world history, the challenge becomes even greater. In the last section, I will discuss some approaches to moving away from the nation state as the dominant method of choosing and organizing the content for teaching history.

I have argued for integration of more non-national and non-western material in the subject history. So it is appropriate to start with the idea of world history, seen as " $[\ldots]$ the construction of a horizon of historical perception which comprises the globe, humanity, and general developments in the sense of "global trends" and "big issues"" [15] to cite the German historian Susanne Popp. Unlike for instance the USA, the Danish and almost all other European school systems do not have separate courses in world history. However, especially in the curriculum for lower secondary school history, topics and themes from world history are mentioned. In spite of his study area being school history in the USA, it is relevant to use the American historian Ross E. Dunn and his four competing models of world history as a framework for the discussion [26].

The first model Dunn calls the Western Heritage Model. Here the content of school history focuses on coherent development of a European civilization process from Mesopotamia to Mediterranean to modern Europe. The process has, so to speak, been running by itself-without external drivers - dedicated to democracy and freedom and other values. According to the model, Western civilization has been a frontrunner for the last 4-500 years. In the beginning of the 20th century the message in the history textbooks was that other more backward civilizations can and should learn from this. A Danish example is Nordahl Rolfsen's Mindre Verdenshistorie (Small World History) from 1905 starting with the Ancient Greece and ending with a chapter called "Fredstanker" (Peace Thoughts) claiming that Western civilization has reached a stage where war is impossible [27].

Of course, this "White Man's Burden" syndrome is not so explicit in modern textbooks, and proponents of this model do not deny the existence of other cultures or civilizations, but they nevertheless consider the European/Western as something special. For instance the Danish historian 
Søren Mørch, who 1990-1991 edited the publication Det Europaiske Hus (The European House), claimed that European civilization and values - human rights, freedom of speech and so on-is something special (author's translation from Danish to English):

"It is not on a level playing field that we can meet (with non-European cultures and civilizations). And we might as well make it clear to ourselves and to others that we demand our own cultural values respected ahead of others [...]. We are not only entitled to speak up about these values. We are even obligated to do so." [28]

Many Scandinavian textbooks aimed at making the upper secondary level historical overview fit into the Western Heritage Model, starting with Mesopotamian and Egyptian cultures of the river valleys.

Dunn's second framework is the Different Cultures Model, which arose in the 1960s and 1970s in the wake of the critique of Eurocentrism and when what was called the third and fourth world came more into focus in history, social sciences and other school subjects. This was the launching of a more multicultural approach to history, which not only focused on non-European cultures, but also the history of minorities, women, working people, young people, and others. Topics about the cultures of Aztecs, Mayas, Incas and the prairie Indians and the white man's conquest are seen from the native peoples' perspective, the oppressive apartheid regime in South Africa, decolonization, the Palestinians' and other non-European nations' attempts to free themselves were popular topics in Danish school history, especially during the 1970s and 1980s.

Contemporary Studies is the third of Dunn's patterns. Here topics and themes are chosen on the basis of current but fundamental international issues, or across cultural and political challenges and problems, for instance " [...] economic globalization, international migrations, global culture, national or ethnic conflict, warfare, peace studies, environmental change [...]". And the task of the teaching is to investigate the historical background for these challenges and problems. This approach is hardly distinguishable from what the German professor in general education Wolfgang Klafki has discussed as a criterion for the choice of teaching content for many years: epoch-typical key issues (epochaltypische Schlüsselprobleme).

For Klafki "The key issues are any topics which truly challenge a contemporary society's future" [29] and by making the key issues the focus of teaching serves to enhance citizenship. According to Klafki the most important key issues are:

- The issue of peace in the world

- The question of the national (history and culture) in relation to the international and global

- Environment and sustainability

- The growth of the population

- The issue of societal inequality (between social classes, men and women, etc.)

- The relationship between the rich countries and developing countries

- Challenges and opportunities of new technology

- Tension between individual happiness and human responsibility

- Opinion questions - ethical and religious orientation problems. 
An epoch-typical key issue such as "Tension between individual happiness and human responsibility" contains a large number of relevant topics that go beyond the nation state.

Another option is to select the content on the basic of what can be described as fundamental and eternal life issues - or common human existence themes. A topic in history can be formulated and organized based on themes such as:

- Important/powerful persons (e.g., children's relationships with adults)

- Yourself and others as sexual beings. Male vs. female

- Requirements and resistance from nature, yourself and others

- To be part of a community and responsible for other people's lives and happiness

- Your own and others' individual existence (life and death)

- What actions and attitudes are good/bad — and what is good and the evil?

- Confusion and chaos

- The need to create meaning and coherence [30].

Inspired by German history teaching the historical consciousness concept was implemented in the Danish history curriculum in 1995. In Denmark-and to some extent in the other Nordic countries - some history teaching researchers tried to give the concept of historical consciousness a special perspective by focusing on children and downplaying the traditional science-based historical content. The primary requirement for the selection of content was close connection to students' everyday life and world. Therefore, it was necessary that school history freed itself from the scientific subject. In addition, because the starting point should be the student and not history as such, it was also necessary to break with the traditional chronological organization of content. So if the history teachers followed the intentions of the curriculum and its understanding of the concept of historical consciousness in the selection of content, they could have derived inspiration from Klafki or the above-mentioned themes of common human existence. This did not happen. One explanation may be that it was difficult to break with a long tradition of selecting and organizing content in school history. Secondly, the curriculum was designed very widely and set the stage for relatively free interpretations without any guidance on how teachers specifically selected content and prepared it for teaching. Thirdly, there were no teaching materials directed at the intentions of the curriculum.

Dunn's fourth approach is the Patterns of Change Model and he mentions other American historians such as William McNeill and Leften Stavrianos as inspirations for this model. "All of them shared a conviction that the nation state was an inadequate framework for understanding the sweep of the human past." [31]. McNeill argued that in an increasingly globalized world it was necessary to develop a kind of world history, an ecumenical history, i.e., a history for humanity as a whole:

"Instead of enhancing conflicts, as parochial historiography inevitably does, an intelligible world history might be expected to diminish the lethality of group encounters by cultivating a sense of individual identification with the triumphs and tribulations of humanity as a whole. This, indeed, strikes me as the moral duty of the historical profession in our time. We need to develop an ecumenical history, with plenty of room for human diversity in all its complexity." [32] 
McNeill has written several books and articles with specific views on what he calls "ecumenical history". I will just mention one with the telling title: "How the Potato Changed the World's History" [33]. Other historians have written textbooks aimed at giving the students a world historical overview, for instance David Christian: "This Fleeting World. A short History of Humanity" in 113 pages [34].

However, is it at all possible to write a coherent world history? One of the main obstacles is the non-simultaneity of events and stages of developments. Even in European history, the chronology is difficult. For instance around 4,000 BC, people in Southern Europe lived as farmers, while people in Northern Europe were hunters and gatherers. Many European textbooks on world history use European chronology as a framework. As Alan J. Singer points out, the result is not a coherent world history but European history with tangents [35]. So perhaps it is necessary to give up absolute chronology as the main principle for organizing the content and instead use a thematic approach in teaching world history. A simple method is to use stages or types of societies defined from an economical or production viewpoint:

- Societies of hunters and gatherers

- Societies of agriculture and cattle breeding

- Societies of industrialization

- Societies of post-industrialization (knowledge societies)

Singer has developed a theme-based global history consisting of "nine roughly chronological calendar areas of study (CAS)" 36]:

- The Human Experience-The first 100,000 years

- Developing the Civilization Package-The Next 10,000 Years

- Rise and Fall of Local States and Regional Empires, 750 BC-1600 AD

- Emerging Networks of Exchange, Mostly 300 AD-1200 AD

- Regional Conflict and Growth (basically 1200 AD-1500 AD with extensions and comparisons on both ends)

- Columbian Exchange, 1420-1763

- Capitalist Transformation, 1750-1914

- $\quad$ Reaction and Revolution, 1914-1989

- Emerging World Order, 1989 to Present.

Although Singer gives several examples of non-European topics, events and persons fitting in each CAS, he sees some problems in integrating important aspects of Chinese history-perhaps because he partly holds on to the chronology, but mostly because although his intention is to formulate a theme-based global history, the mentioned areas of study (CAS) are not quite released from the traditional periods and epochs used in traditional European history. 


\section{Summary}

Finally, a few didactic considerations: A key requirement for the teaching of history is to strengthen the students' historical consciousness, i.e., to use their knowledge of history to understand their present (their life-world) and relate it to their future prospects. This is a challenge in organizing teaching focusing on the nation state alone - and may be even more difficult when the topic is world history. So the teacher must be aware of establishing clear and relevant perspectives from the local or micro-level life-world of the students to the macro-level of global topics or trends and vice versa.

The curricula in England, the German federal states and the Scandinavian countries emphasize a problem-orientated approach to teaching history, where students are actively seeking answers to questions - ideally formulated by themselves in practice but usually by the teacher or teaching materials - about historical phenomena. To integrate world history in teaching, the teacher encourages students to practice asking broader questions-more precisely like Klafki, for instance, but directed towards the idea of the history of humankind and its shared experiences. In this context, Susanne Popp has some concrete suggestions. One is to let the student examine world history maps from issues such as "... the configuration of major political and cultural entities in the contemporary past... the configuration of the most important trans-regional and trans-cultural interlinks and networks... about "global trends and "big questions" of a certain era..." [15]

Although the Danish national curriculum for history-like that of other countries - is mainly directed towards the national historical narratives, the statements about the content are open. Therefore, it is possible and quite legitimate to integrate global dimensions in teaching history to a greater extent. Perhaps one obstacle is the lack of appropriate learning materials, but perhaps even more it is the traditional culturally conditioned concept of the school subject.

\section{Conflicts of Interest}

The authors declare no conflict of interest.

\section{References}

1. Undervisningsministeriet. Falles Mål 2009. Historie Faghaefte 4. Undervisningsministeriets håndbogsserie nr. 4, 2009: København, Denmark. Available online: http://www.uvm.dk/Service/ Publikationer/Publikationer/Folkeskolen/2009/Faelles-Maal-2009-Historie (accessed on 26 October 2013).

2. Utdanningsdirektoratet. Available online: http://www.udir.no/Lareplaner/Finn-lareplan/\#samfunnsfag (accessed on 26 October 2013).

3. Thüringer Ministerium für Bildung, Wissenschaft und Kultur. Lehrplan für den Erwerb des Hauptschul-und des Realschulabschlusses Geschichte. 2012. Available online: http://www. schulportal-thueringen.de/lehrplaene/regelschule (accessed on 26 October 2013).

4. Undervisningsministeriet. Falles Mål 2009. 'Historie Faghaefte 4. Undervisningsministeriets håndbogsserie nr. 4, 2009, 3.

5. Thüringer Ministerium für Bildung, Wissenschaft und Kultur. Lehrplan für den Erwerb des Hauptschul- und des Realschulabschlusses Geschichte, 2012; p 5. 
6. Undervisningsministeriet. Falles Mål 2009. 'Historie Faghaefte 4. Undervisningsministeriets håndbogsserie nr. 4, 2009; p7.

7. Meloni, Thomas. Indblik og udsyn. Historie for 9. Klasse. Nyeste tid 1918-2010; Meloni: Odense, Denmark, 2010.

8. Department for Education. History Available online: http://www.education.gov.uk/schools/ teachingandlearning/curriculum/secondary/b00199545/history (accessed on 26 October 2013).

9. Shephard, C.; Reid, A.; Shephard, K. Discovering the Past Y9. Peace \& War; John Murry: London, UK, 1996.

10. Senatsverwaltung für Bildung, Jugend und Sport. Rahmenlehrplan für Sekundarstufe I. Jahrgangstufe 7-10. Hauptschule, Realschule, Gesamtschule, Gymnasium. Geschichte; Berlin, Germany, 2006. Available online: http:/www.berlin.de/imperia/md/content/sen-bildung/ schulorganisation/lehrplaene/sek1_geschichte.pdf?start\&ts=1150101699\&file=sek1_geschichte. pdf (accessed on 26 October 2013).

11. Brückmann, A.; Brütting, R.; Gautschi, P.; Hambach, E.; Horst, U.; Langen, G.; Offergeld, P.; Sauer, M.; Scherer, V.; Wallmeier, F. Geschichte Geschehen. Sekundarstufe I. Band 2; Ernst Klett Schulbuchverlag: Leipzig, Germany, 2009.

12. Utdanningsdirektoratet. Curricula in English. Primary and Lower Secondary Education. Available online: http://www.udir.no/Stottemeny/English/Curriculum-in-English/_english/ Curricula-in-English (accessed on 26 October 2013).

13. Skjønsberg, Harald: Undervegs. Historie 8. Samfunnsfag for Ungdomssteget; Gyldendal: Oslo, Norway, 2006.

14. McNeill, W. Mythistory and Other Essays; The University of Chicago Press: Chicago, IL, USA, 1986.

15. Popp, S. Integrating World History Perspectives into a National Curriculum: A Feasible Way to Foster Globally Oriented Historical Consciousness in German Classrooms? Available online: http://worldhistoryconnected.press.illinois.edu/3.3/popp.html (accessed on 26 October 2013).

16. Dunn, R.E. Western Civ., Multiculturalism and the Problem of a Unified World History. Conference Paper, Marts 1995. Available online: http://www.eric.ed.gov/ERICWebPortal/search/ detailmini.jsp?_nfpb=true\&_\&ERICExtSearch_SearchValue_0=ED388585\&ERICExtSearch_Sea rchType_0=no\&accno=ED388585 (accessed on 26 October 2013).

17. Thomas Elyot, T: The Book Named the Governor; Lehmberg, S.E., Ed.; Everyman's Library: London, UK, 1975.

18. Sommers, J. Historical Arabesques: Patterns of History. Available online: http://worldhistoryconnected.press.illinois.edu/5.3/Sommers.html (accessed on 26 October 2013).

19. Dunn, R.E. Constructing World History in the Classroom. In Knowing, Teaching, and Learning History: National and International Perspectives; Stearns, P.N.; Seixas, P.; Wineburg, S. Eds.; New York University Press: New York, NY, USA, 2000, p.121.

20. Pietras, J.; Poulsen, J.A. Historiedidaktik - fra Teori til Praksis; Gyldendal: København, Denmark, 2011; p 51.

21. Helms, N.M. De Danske og deres Broderfolk; Gyldendal: København, Denmark, 1916.

22. Undervisningsministeriet. Undervisningsvejledning for Folkeskolen. Betankning Afgivet af det af Undervisningsministeriet under l. September 1958 Nedsatte Laseplansudvalg. Betankning nr. 
253;S.L. Møllers Bogtrykkeri: København, Denmark, 1960; p.118.

23. Undervisningsministeriet. Historie Faghafte 4; Undervisningsministeriet, Folkeskoleafdelingen: København, Denmark, 1995; p. 12.

Undervisningsministeriet. Klare Mål. Historie; Uddannelsesstyrelsens håndbogsserie nr. 4, København, Denmark, 2002; p. 19.

Undervisningsministeriet. Falles Mål. Faghafte 4. Historie; Undervisningsministeriets håndbogsserie nr. 4, København, Danmark 2004; p. 44.

24. Haydn, T. History in Schools and the Problem of "The Nation". Educ. Sci. 2012, 2, 276-289.

25. Undervisningsministeriet. Rapport fra Udvalget til Styrkelse af Historie $i$ Folkeskolen; Undervisningsministeriet, Folkeskoleafdelingen: København, Danmark, 2006; p. 3. Available online: http://www.uvm.dk/Uddannelser-og-dagtilbud/Uddannelser-til-voksne/Overblik-overvoksenuddannelser/Almen-voksenuddannelse/Fagene-under-almen-voksenuddannelse/Historie-avu / /media/UVM/Filer/Udd/Voksne/PDF07/H/historie_000.ashx (accessed on 26 October 2013).

26. Dunn, R. Issues in Global Education. Newsletter of the American Forum for Global Education Available online: http://www.globaled.org/issues/151 (accessed on 26 October 2013).

27. Rolfsen, N. Mindre Verdenshistorie; H. Hagerup's Forlag: København, Denmark, 1905; pp. 186-188.

28. Mørch, S. Civilisationen; Gyldendal: København, Denmark, 1991; pp. 336-337.

29. Graf, S.T.; Skovmand, K.. Fylde og form Wolfgang Klafki i Teori og Praksis; Klim: Aarhus, Denmark, 2004; p. 39.

30. Pietras, J.; Poulsen, J.A. Historiedidaktik—Fra Teori til Praksis; Gyldendal: København, Denmark, 2011; p. 164.

31. Dunn, R.E. Constructing World History in the Classroom. In Knowing, Teaching, and Learning History: National and International Perspectives; Stearns, Peter N.; Seixas, P.; Wineburg, S. Eds.; New York University Press: New York, NY, USA, 2000.

32. Lorenz, C. Drawing the Line 'Scientific' History between Myth-making and Myth-breaking. In Narrating the Nation Representation in History, Media and Arts; Berger, Stefan; Eriksonas, Linas: Mycock, Andrew; Berghahn Books; USA, 2008; p. 40.

33. McNeill, W.H. How the Potato Changed the World's History. In Social Research; Spring 99, Volume 66, Issue 1, pp. 67-83.

34. Christian, D. This Fleeting World. A short History of Humanity; Berkshire Publishing Group LLC: Boston, MA, USA, 2008.

35. Singer, A.J. Teaching Global History. A Social Studies Approach; Routledge: New York, NY, USA, 2011; pp. 39-47.

36. Singer, A.J. Teaching Global History. A Social Studies Approach; Routledge: New York, NY, USA, 2011; pp. 61-87.

(C) 2013 by the authors; licensee MDPI, Basel, Switzerland. This article is an open access article distributed under the terms and conditions of the Creative Commons Attribution license (http://creativecommons.org/licenses/by/3.0/). 